\title{
ILCEA
}

Revue de l'Institut des langues et cultures

d'Europe, Amérique, Afrique, Asie et Australie

$30 \mid 2018$

Création culturelle et territoires : de l'histoire au

mythe, du réel à l'utopie

\section{Utopia in the Age of Realism: Theodor Fontane's Quitt}

L'utopie à l'ère du réalisme: Quitt de Theodor Fontane

\section{Michael White}

\section{(2) OpenEdition \\ Journals}

Electronic version

URL: http://journals.openedition.org/ilcea/4499

DOI: $10.4000 /$ ilcea.4499

ISSN: 2101-0609

Publisher

UGA Éditions/Université Grenoble Alpes

Printed version

ISBN: 978-2-37747-033-4

ISSN: 1639-6073

Electronic reference

Michael White, «Utopia in the Age of Realism: Theodor Fontane's Quitt », ILCEA [Online], 30 | 2018

Online since 31 January 2018, connection on 19 April 2019. URL : http://journals.openedition.org/

ilcea/4499; DOI : 10.4000/ilcea.4499

This text was automatically generated on 19 April 2019.

(C) ILCEA 


\title{
Utopia in the Age of Realism: Theodor Fontane's Quitt
}

\author{
L'utopie à l'ère du réalisme: Quitt de Theodor Fontane
}

\author{
Michael White
}

\section{Introduction}

1 Approaching nineteenth-century German literature, specifically mid- to late nineteenthcentury literature through the theme 'utopia' seems, at first, an unusual undertaking. After all, for the major authors of the nineteenth-century theirs is the age of Realism, of being realistic in a broad sense, turning away from metaphysical speculation to the "Leben, das wir führen". ${ }^{1}$ This is a bourgeois age whose poetics articulates and represents recognisable and existing problems, people, and worlds. Theodor Fontane's assessment of his age remains perhaps the most famous in the German context:

Was unsere Zeit nach allen Seiten hin charakterisiert, das ist ihr Realismus. Die Ärzte verwerfen alle Schlüsse und Kombinationen, sie wollen Erfahrungen; die Politiker (aller Parteien) richten ihr Auge auf das wirkliche Bedürfnis und verschließen ihre Vortrefflichkeitsschablonen ins Pult; Militärs zucken die Achsel über preußische Wehrverfassungen und fordern „alte Grenadiere“ statt ,junger Rekruten“; vor allem aber sindes die materiellen Fragen, nebst jenen tausend Versuchen zur Lösung des sozialen Rätsels, welche so entschieden in den Vordergrund treten, daß kein Zweifel bleibt: die Welt ist des Spekulierens müde und verlangt nach jener "frischen grünen Weide", die so nah lag und doch so fern. (Plumpe, 2005: 141)

Indeed, this realism of nearness, as Fontane describes it, which conflates the familiar ("alte Grenadiere"), with the solid and empirically knowable, promotes a specific literary topography too: rather than the presentation of new and ideal worlds the novel of the age is characterised by a "Rückkehr in die Heimat", a trope we find in texts as diverse as Keller's Pankraz der Schmoller, Stifter's Hagestolz, and Fontane's Der Stechlin. ${ }^{2}$

The cultural change of focus and mentality Fontane summarises is reflected in the history of utopian literature, which underwent a marked decline in the middle of the century, as 
several commentators have noted. In his treatment of utopianism, Krishan Kumar notes the relative decline of the utopia after the eighteenth century and its re-emergence only at the end of the nineteenth (1991:59). Within a more specifically German context, Wolfgang Biesterfeld notes in his bibliographical survey an "utopische Lücke" between 1849 and 1874, between the post-revolutionary years and the new political age of the Gründerzeit (1974: 63). As Kumar notes, specifically literary forms of utopias declined as the place of philosophical and political innovation and commentary, and were supplanted by political and social theory in the age of science: "In the main, the literary utopia went into abeyance, to re-emerge only at the end of the nineteenth century. If utopianism continued to flourish-and it did-it did so in the form not of the classical literary utopia, but of utopian social theory." (1991:59). The nineteenth-century discussion about the best possible world becomes a "battle of the systems", rather than a literary exploration (Manuel \& Manuel, 1979: 581).

If it is in this environment that Realism emerged and flourished, by the 1890s the literary scene had changed. Arthur Kirchenheim's 1892 study of the Staatsroman genre and its history was motivated by what he describes as a flood of socialist and communist novels depicting future states, something Kirchenheim characterises specifically as the reappearance of a genre after a period of absence and in new conditions (1892: 2). Fontane is an author at once of the Realist generation but whose canonical works were produced in this new context of the 1880s and 1890s, a Dichter des Übergangs as Patricia Howe has called him and as such he not only offers an opportunity of assessing the impact of these new trends on the established Realist literary tradition; analysing his work from the perspective of literary utopias can also highlight his position as an author whose work needs to be considered within the context of specifically late nineteenth-century poetics and literary life, as well as in the light of the German Realist tradition, with its roots in the 1830s and 1840s (Howe, 2013).

5 It is relatively likely that Fontane was aware of authors like Kurd Laßwitz (1848-1910), Harro Harring (1798-1870), and Gottfried Doehler (1863-1943) whom Kirchenheim lists in his survey of late nineteenth-century utopian authors in Germany (Kirchenheim, 1892: 264), though direct links are hard to find: Fontane was offered, but refused to review Doehler's play Im Zukunftsstaat, for example. ${ }^{3}$ Certainly, Fontane's letters demonstrate that he knew of, and was sympathetic to Eugen Richter, whose own 1891 Sozialistische Zukunftsbilder is an ironic dystopian vision of a socialist future state, but these references are not to Richter's writing. ${ }^{4}$ As a journalist and famously avid newspaper reader, it is, nevertheless, almost certain that Fontane was aware of the general rise of utopian literature. A search of the liberal journal Die Grenzboten (1841-1922), for example, shows a marked increase in the frequency of the term Utopie, which occurs around once per decade before 1890, and then almost yearly after that. ${ }^{5}$ The term Zukunftsbild demonstrates a more dramatic growth in frequency, occurring in first in the 1870s, then several times during the 1880s, then yearly from the 1890s. ${ }^{6}$ Whatever Fontane's own knowledge of, or views on contemporary literary utopias or dystopias, it is in this changed literary context that the novel Quitt appears in 1890, a novel whose second part is set in America, in, as Hans Heinrich Reuter has called it, a new world in every sense of the term (Reuter, 1971: 1371-76).

6 In our examination of Quitt as a utopian novel, we understand 'utopia' to have several overlapping senses which are variously explored by the novel, but principally we distinguish between utopia as a place, an ideal society which exists in a distant location 
within the text's fictional reality, in other words utopia as it relates to the literary tradition which includes Thomas Moore and German Staatsromane; but by utopias we also include imagined realms within the text and utopian modes of thought. It is the sociologist Karl Mannheim who uses the term 'utopian' to describe a particular kind of world view (Mannheim, 1968).7 In Mannheim's analysis, "ideological" and "utopian" are opposite terms because they describe, respectively, those in power and who wish to preserve the social order on the one hand, and those who seek to change the given order on the other. In both cases, these groups' predispositions prevent them from perceiving reality fully. For the purposes of this essay, we shall not adopt the term "utopian" in the restricted sense that Mannheim uses it; rather, we demonstrate how Fontane associates his literary utopias as places with ways of thinking about reality which we can analyse as "utopian" because they contrast their given immediate reality with another, often imagined, idealised, or non-existent level of thought, a Gegenwelt of the mind. What we shall demonstrate is that in Quitt Fontane engages with utopia as a literary tradition, that is, he writes a novel which can be read as a utopia, but in so doing he examines utopianism more broadly, presenting utopias and utopianism within a spectrum of unrealistic, prejudiced or ideal perceptions of the world.

\section{The narrative and its reception}

7 The plot of Quitt is, as so often with Fontane, essentially simple, and a foil for other issues which are primarily to do with psychological, social, or poetological commentary. The first part of the narrative is set in a Silesian village, Krummhübel and the surrounding area. Lehnert Menz is a young carpenter and former soldier who lives with his old mother next to the forester Opitz and his wife. The relationship between Opitz and Lehnert is antagonistic, in part because Opitz had underhandedly prevented Lehnert from being awarded the Iron Cross in the Franco-Prussian War and saw to it that he instead spent time in prison; but their difficult relationship stems also, indeed primarily, from their characters. Opitz has an inflated sense of his own social position, rights and duties as a Mann im Dienst, something Lehnert, as a temperamental young man with a pronounced desire for independence, finds difficult to flatter for the sake of harmonious and neighbourly relations. The first part of the narrative traces the development of this relationship between the forester's arrogant and arbitrary inflexibility on the one hand, and the "bewegliches Gemüt" of Lehnert on the other. ${ }^{8}$ The intercessions of the local priest, Siebenhaar, and other characters such as Opitz's maid, Christine, bring about a temporary lull in their feud: at first Lehnert avoids Opitz, then he attempts to feign respect. But a combination of small events intervenes: Lehnert hears of Opitz's criticism of him despite his best efforts to be accommodating; Opitz's dog kills the Menz's hen of which Lehnert was very fond; and finally Opitz appears to be ready to have Lehnert prosecuted for having shot and kept a hare. Frightened at the thought of having to return to prison, and unwilling to run away, Lehnert disguises himself and sets out into the mountains in the evening, pretending that he will allow fate to decide whether he should meet and confront Opitz. He goes to a place he knows Opitz is likely to be and, when Opitz's gun fails to fire, he shoots him. Fatally wounded, Opitz remains alone on the mountain, dying only the next day. When his body is discovered by a search party, Lehnert is immediately suspected, and when officials arrive to search his house, he escapes. We discover him six years later in America and follow him as he settles on a 
Mennonite farm, Nogat-Ehre, in Indian territory, and here the second half of the novel unfolds. It is characterised by relatively little action, instead introducing a new panoply of characters, of whom the most significant are Obadja, the pater familias and owner of the farm, and L'Hermite, a former communard. Though much of Lehnert's behaviour demonstrates that he has matured, he is constantly reminded of his past crime which prevents him finding real peace. His fate eventually catches up with him as he too dies alone on the mountain, signing in blood his hope that his debt has been repaid, that he is quitt.

8 The novel is generally seen as one of Fontane's weaker works-the "künstlerisch mißlungenste" (Grawe, 2000: 587) 9 -, although newer research has attempted to offer a more balanced picture. For James Bade, the principal interpretative stumbling block for critics has traditionally been the representation of America in the novel, which has been judged either unrealistic, purely imagined, or derived from other fiction, lacking the same quality and authenticity that the first part of the novel possesses (Bade, 2015). Bade's detailed research of maps and visits to the places involved indicate that, despite the fact that Fontane never travelled to America, his landscapes were, nevertheless, based on both more research and more realistic data than was previously assumed to be the case. The relatively new edition of the Aufbau Große Brandenburger Ausgabe, edited by Christine Brieger, which appeared in 1999, presents a wealth of information on the critical reception of the novel, giving, in general, a more favourable account of the novel's reception than might be expected from the place of the novel in assessments by twentieth-century critics. Of particular note here are favourable comparisons made by Fontane's contemporaries, such as Bruno Wille, to Dostoyevsky's Crime and Punishment, because of Quitt's long second half which concentrates on how the protagonist bears his guilt (Brieger, 1999: 330-1). While there is no space here to trace the novel's reception further, both Brieger's presentation of contemporary reviews, and other surveys of twentieth-century scholarship such as that offered by Charlotte Jolles (1993: 67-70), demonstrate that there are principally three areas of debate around the novel: first, the novel's settings, in particular the American setting; second, the novel's two part composition; and third, the issue of fate. It shall be our purpose to demonstrate that an assessment of the theme and representation of utopia in the novel contributes to all three of these discussions.

9 There have been two previous examinations of the novel which consider the text from the perspective of utopias specifically: Hans-Heinrich Reuter's short treatment from 1971, published in the East German journal Sinn und Form, and Brieger's own short interpretative essay which forms part of the 1999 Aufbau edition. Reuter's principal aim is to explain the text's formal disunity in terms of its place in political and literary history, an argument he makes with characteristic verve and energy, and which warrants quoting at length:

Quitt entsteht in einer Epoche folgenreichster sozialer und politischer Umwälzungen: zu Beginn der imperialistischen Ära und in derselben Zeit, da die kämpfende deutsche Arbeiterbewegung ihren größten Sieg im ausgehenden 19. Jahrhundert erring. Wenige Wochen vor dem Erscheinen der Buchausgabe des Romans muß die kaiserliche Regierung das Bismarcksche Sozialistengesetz aufheben, ein Jahr danach wird der Erfurter Programm der deutschen Sozialdemokraten beschlossen.

Wir kennen keinen vergleichbaren zeitgenössischen deutschen Schriftsteller, der diese Entwicklung mit ähnlich produktiver Aufgeschlossenheit verfolgt, der so 
weitreichende poetische Konsequenzen daraus gezogen hat wie Fontane. (Reuter, 1971: 1372) there are a number of other important themes and insights that have occupied Fontay scholars which are relevant to the present discussion of Quitt and to the question of utopias in Fontane's work more broadly. Reuter's analysis of Quitt as a utopia in 1971 accorded with a range of publications in the same decade around literary utopias. ${ }^{10}$ In Fontane scholarship, the idyll has been more the focus of attention, being the object of Cordula Kahrmann's monograph study (1973). Perhaps the most significant aspect of that research for present purposes is the fact that the analysis proceeds from the position that nineteenth-century novels absorb motifs and tropes of the idyll, which was previously a specific genre in which idyll and reality functioned as a structural oppositional pair, one that can be traced through Fontane's narrative prose. This concurs with the findings of studies of utopian scenes in Fontane's other works, such as Cornelie Ueding's analysis of Cécile (1978). The consideration of the place of happiness, a eu-topia (Claeys, 1999: 1), has been identified in itself as a core theme in Fontane's prose, by Bettina Plett (2000), and from a more narratological perspective by Klaus R. Scherpe (2000); both underscore the importance of place and belonging for individuals, the organic interwovenness of identity and social and local milieu, to the extent that, for Scherpe, moving out of one's place can be seen as the recurrent root of negative events in Fontane's plots. As we shall see, Fontane's Quitt not only depicts a utopian realm, it engages with something we might term the "utopian mentality", with the influence that ideals and ideologies have on our perception (Mannheim, 1968: 173). Here John Walker's recent monograph on Fontane's Realism as a realism which represents and critiques ideologies is also of relevance (Walker, 2011). The continued discussion of utopias contributes to all of these ongoing fields of research.

13 Nogat-Ehre can first be considered as a utopia in the sense of an ideal community located in a distant place, in particular as a Gegenwelt, in this case to the Silesian community to which Lehnert flees. As we shall see, this basic division in the novel is complemented by a 
range of other spatial pairs and metaphors which relate the larger opposition of communities and places to smaller, more personal relationships. We will then proceed to consider utopian thought, or rather, the various ideological positions adopted by characters and groups throughout the novel, the ideals through which they assess and judge the world, most obviously Lehnert's actions, but also their own experiences, each other and society in general. Analysed from this perspective, the novel does not appear merely as the depiction of a bad society and a better one; rather, what is at stake in the novel is the function and significance that ideals, imagined or remembered, political, cultural or moral, have in our assessment of reality and in our judgement.

\section{Utopia as place}

14 Like Unwiederbringlich (1891) with which it shares a common period of genesis (Quitt [ 1885-1889]; Unwiederbringlich [1887-1890]), Quitt is organised essentially around two antithetical worlds: Krummhübel and its environs in Silesia, and Nogat-Ehre in Indian Territory in the United States. Although Nogat-Ehre is a fictional place, most of the surrounding locations, names, and many of the characters' names derive from real sources, as James Bade has persuasively and exhaustively argued. From this point of view, Nogat-Ehre does not seem to be a utopia in the sense of a Nicht-Ort or non-existent but idealised place, but rather a plausible location where Fontane situates a society which is to be read as an alternative possibility to the Silesia Lehnert leaves behind. As Bade summarizes: "In Obadja's Mennonite community Fontane sketches out a working alternative: a thriving tolerant and supportive community that is not based on authoritarianism or blind obedience, but on common sense." (2015: 45)

Certainly, there is much to recommend this interpretation. Lehnert's experience in Silesia and the general representation of society there are clearly highly critical, above all in the figure of Opitz, the bullish and bullying Duke's servant, who wants to be treated as a Respektsperson; but other figures play a role here too, such as Lehnert's pathetically deferential mother, whose very speech and mannerisms become dehumanised in her fawning, or the ineffectual pastor Siebenhaar, whose proposed solution to Lehnert is, it seems, to accept Opitz's behaviour and turn the other cheek. In addition, the representation of the Silesian milieu constantly emphasises its own closeness to its contemporary readership, through, for example, comic references to Berliners, to tourists, and indeed because of the rooting of the conflict in the Franco-Prussian war. Fontane's Silesian setting also assumes, or appears to assume, a complicit knowledge on the part of the reader, as the landscape is built up largely through proper names and with a minimal quantity of description, which again promotes familiarity.

The small 'happy family' in the Mennonite community in America represent, by contrast, a community that lives outside the government controls that Opitz represents: one of the first things Lehnert discovers about the settlement is that Obadja, the paternalistic leader of the group, had moved out into Indian Territory precisely to avoid government oppression (327). Furthermore, if Lehnert was driven out of Silesia because of his crime, he is accepted into Nogat-Ehre in spite of it, and indeed becomes more closely integrated into the community when he is accepted into the Mennonite faith and confesses, privately, to Obadja (378). Whereas Lehnert and his mother live very modestly in Wolfshaubei Krummhübel (let us not forget that Lehnert shoots a hare for his mother to cook, a hare which was on his own field, and it is this action that leads to his final rift 
with Opitz), Lehnert is well-cared for in Nogat-Ehre, which, as a large farm, marks a clear contrast with his small potato field at home. Not least the representation of the Mennonite society seems to balance meritocracy and paternalism: Lehnert is welcomed in part because he can work and work and talent are valued, despite personality or religion; at the same time, old servants eat their Gnadenbrot, which contrasts with Lehnerts fears in Silesia that his mother would be helpless without him there to care for her. Above all, it is the spirit of the place that is different, because Nogat-Ehre is characterised by respect and virtuous living. Obadja commands great loyalty in work and personal respect from the members of the community because they value his wisdom and tolerance: Lehnert, as the narrator relates, "sah kein Regieren, und einfach ein Geist der Ordnung und Liebe sorgte dafür, daß alles nach Art eines Uhrwerks ging" (346). This stands in obvious contrast to Opitz's claim to respect, and to his lack of personal qualities that might command the deference of his fellowmen.

The underlying antithesis between the Silesian setting and Nogat-Ehre is part of the novel's structural mirroring of a question which is posed within the narrated action: "Wo liegt das Glück?" In a sequence in Chapter 6, Lehnert's mother goes to a wedding, which the narrator introduces as follows:

Nun war wieder Sonntag, und die Glocken der Arnsdorfer Kirche klangen wie gewöhnlich vom Tal zu den Bergen herauf. Aber diesem Rufe folgten heute nur wenig, weil oben in der Kirche Wang ein Brückenberger Paar getraut werden sollte. (245)

18 Lehnert however, looking to avoid Opitz, prefers to stay at home, and reads in his book about America:

Bis gegen Abend saß er draußen im Freien und las von Urwald und Prärie, von großen Seen und Einsamkeit. Er schwelgte darin und vergaß die Zeit, aber mit einmal ergriff ihn doch ein Grauen: „Einsamkeit! Nein, nein, nicht Einsamkeit. Nicht einsam leben, nicht einsam sterben." Und er wiederholte sich das Wort, und in seiner überreizten Einbildungskraft sah er sich auf einem Bergkegel, ein Tal zu seinen Füßen und den Sternenhimmel über sich. (246)

After a discussion with his mother, Lehnert then goes to bed, and before extinguishing the light, he re-reads the title of his book: “"Die Neue Welt oder Wo liegt das Glück?"” (248). I have quoted these passages at length because they demonstrate the interconnectedness of the fundamental question the book poses, Wo liegt das Glück?, with smaller details. Here, for example, the section of the narrative in question begins with the image of two churches, a choice that the locals have between attending their normal church or attending a wedding, a social event; it closes with the explicit articulation of the question the segment has already posed by other means. In short, the question of "utopia" in the novel sheds light on the narrative beyond the representation of Nogat-Ehre, because the question where happiness lies is relative and occurs in small ways even within the Silesian context, within everyday life.

As the above example demonstrates, the opposition between Silesia and Nogat-Ehre functions as the overall structural reflection of a basic question that affects Lehnert most obviously, and for which he is the mouthpiece; this overall structural opposition is in turn replicated in smaller spatial metaphors and distinctions which permeate the text and afford it a sense of coherence which has not always been appreciated by critics. Indeed, the division of the novel into two halves is felt, even in Grawe's balanced assessment, to be most significant artistic failing of the text, with the character Lehnert being the only formal point of unity between the two sections. There are however, other structural 
parallels that give a sense of coherence to the text and which mirror the Silesia/America division.

In her notes to the Aufbau edition of the text Christine Brieger rightly draws the reader's attention to the relationship between the spatial setting of the novel, in particular the description of Opitz's and the Menz's houses, and their antagonistic relationship:

Der Konflikt zwischen Lehnert und Opitz beruht auf der Gegensätzlichkeit zweier Weltauffassungen. [...] Ihr Verhältnis zueinander wird u.a. durch die Raummetaphorik ausgedrückt. So impliziert die Bezeichnung „der da drüben“ - in Anspielung auf eine räumliche Grenze - die Unterschiedlichkeit der geistigen Standorte. (Brieger, 1999: 304).

The narrative not only situates the two places in close proximity; the descriptions of the two houses and their situations mirrors the two characters Lehnert and Opitz:

Nichts als Fluß und Fahrstraße trennte beide Gehöfte, deren gesamtes Acker- und Heideland in alten Zeiten ausschließlich Stellmacher Menzsches Eigentum gewesen war, bis man auf dem diesseits der Lomnitz gelegenen Kusselstreifen eine Försterei gebaut und nur alles jenseits des Flusses Gelegene bei den Menzes belassen hatte. Das war jetzt runde dreißig Jahr', und fast ebenso lange hatte man hüben und drüben ohne Neid und Eifersucht gelebt, trotzdem dazu, wie nun mal die Menschen sind, vielleicht Grund gewesen wäre. Denn wenn einerseits die neue Försterei mit ihrer Sauberkeit und ihrem roten Dach die drüben gelegene, hier und da sehr baufällige Stellmacherei weit in den Schatten stellte, so hatte diese dafür die fette Seite behalten [...] Aber das alles hatte die ganze Zeit keinen Ärger geschaffen und noch weniger der zufällige Umstand, daß das auf einer Stein- und Geröllinsel inmitten zweier Lomnitzarme gelegene Menzsche Wohnhaus, so wenig gepflegt es war, doch kastellartig auf alles unmittelbar Umhergelegene herabsah und natürlich auch auf die Försterei. (240)

It is not difficult to see in this description both the grounds of the conflict, the apparent imbalance between the social status of the two buildings on the one hand and their spatial positions on the other, and an allusion to the location of Lehnert's death in America, the loose stones of Lookout Point.

This antithesis in the setting is underscored by smaller spatial references, in particular the adverb "drüben" that recur with notable frequency in this part of the narrative. For example, as Christine suggests to Opitz he could take the moral high ground and be kinder to Lehnert, he replies: "Ja, das glaub' ich. Ich soll anfangen und jeden Morgen, wenn ich ihn drüben hantieren seh', meine Kapp' abnehmen und über die Brück' hinübergrüßen." (236) Later, doubting Lehnert's efforts, Opitz calls him "der große Herr drüben" (265). Similarly, in Chapter 9, when the Menz's hen is killed, Lehnert calls Opitz "den da drüben". Indeed, in the first four paragraphs of the chapter the phrase recurs six times, insistently underscoring the sense of difference and distance between the two neighbours.

It is important to note, however, that other characters articulate relationships in similar ways. The pastor Siebenhaar, in general a positively characterized figure, stops for lunch on his way to the Menz's and sees some tourists:

Touristen von eleganter und beinah weltmännischer Haltung, die trotz ihres prononciert sächsischen Dialekts unschwer erkennen ließen, daß sie viel „drüben“ gewesen sein mußten, in England oder vielleicht gar in America. (251)

Similarly, in Chapter 16, some gypsy travellers with dancing bears and monkeys come past the inn where the Berlin Rechnungsrat Espe and his wife, Geraldine, are eating. Everyone is delighted by the amusing distraction, by the "Stück poetischer, mit dem 
Zauber des fremdartigen ausgestatteter Welt" (318), except Espe who sees it as "Unordnung", "Unsitte". He goes on "ich mag nicht alles auf der Seele haben [...] was sich da drüben bei dem seinwollenden Ehepaare, das doch natürlich keines ist, vorfindet"(319). Espe's pedantic and limited distaste for the morally ambiguous "Gesindel" he sees is of course ironic, given his own wife had their children out of wedlock before she married him, and here Quitt parallels other novels, such as EffiBriest, contrasting Prinzipienreiterei with experience and tolerance. But what is significant for our purposes is that in this distinction that Espe makes between himself and others is articulated spatially, "[sie] da drüben" (319), employing the same discourse as a range of characters, as we have seen.

The important point to be made here is that the overall structure Silesia/America is prefigured in the first part of the narrative through these frequent contrasts between the 'here' and 'there', lending coherence to the novel. Crucially, however, these patterns demonstrate that while the two settings Krummhübel and Nogat-Ehre may well be Gegenwelten, the principal concern of the novel, and thus the primary symbolic content of these spatial settings and metaphors is not really with political organization, but social relationships at a more fundamental level, because the fundamental issues emerge in small, everyday ways too. To get closer to the full significance of these patterns, it is necessary to consider two further spatial metaphors that recur throughout the text.

When Siebenhaar visits Lehnert and proposes that Lehnert do his best to make his peace with Opitz, Lehnert replies “ich geh' ihm aus dem Weg” (259). For Siebenhaar this represents, literally, the avoidance of the issue:

Das ist nicht genug Lehnert. Das vertagt den Streit bloß, aber schafft ihn nicht aus der Welt [...] damit schließt man keinen Frieden, daß man sich aus dem Wege geht [...]. Hier muß es anfangen und hier. Herz und Einsicht müssen dazu zwingen. (259)

Siebenhaar's metaphor contrasts avoidance of difficult moral choices ("aus dem Weg") with the internal, rational and emotional reflection on moral action ("hier"). This same discourse is found in Lehnert's internal thoughts when he sets out to kill Opitz:

Wenn ich mich ranhalte, bin ich in zwanzig Minuten oben. Und dann bin ich ihm nicht begegnet. Aber warum nicht? Weil ich ihm nicht begegnen konnte, weil ich ihm aus dem Wege gegangen bin. Ist das das Rechte? Heißt das sein Schicksal befragen? Ich darf ihm nicht aus dem Wege gehen, das ist kein richtig Spiel; ich muß dahin, wo sich's begegnen läßt... Da ist meinPlatz. (284)

The problem around Lehnert's choice is articulated spatially: in Siebenhaar's way of thinking, "mein Platz" and "da" are antithetical points, as "hier" and "da" are. Whereas Lehnert is warned to start with and within himself, he turns Siebenhaar's argumentation around. This leads, ironically, to the physical action whereby Lehnert, through his own determination, commits a criminal act.

31 It is the relationship between these metaphorical expressions of human moral action and Lehnert's subsequent experiences within the novel's reality that are at the root of the complex and at times overworked fatalistic structure of the novel. Having committed his crime, Lehnert has, in a sense, made his "hier" into "da", he has stepped outside his previous world. As the French communard in Nogat-Ehre L'Hermite will summarise:

Und ein solches Gesetz ist es auch: wenn man erst mal heraus ist, kommt man nicht wieder hinein. Und da hilft kein Hoherpriester und kein Prophet [...]. Das Fatum ist eben starker, und es ist das Beste, cher Lehnert, Ihr lebt Euch mit diesem Gedanken ein. (430) 

Ehre and its relationship to Silesia, i.e. utopia as a place, but also that the novel examines a range of idealised or idealising visions of society, some of which are more general than others, that is utopianism or utopian modes of thought. Many of the novel's characters have an ideal view of the world, a prism through which they view not only their world but also the actions of others, which enter thus into their judgement. The novel explores the significance of political ideology, for example, most obviously conservatism, which is articulated by a range of characters in the text for whom the acceptance of social structures is part of the individual's moral and social duty. Opitz is the chief representative of this in its oppressive form. We note in Christine's description of him how he manipulates the discourse of conservatism to promote his own personal importance and power:

„Nu, Christine, wie gefällt dir das große H?" Und vor allem, weil er gerne so was schreibt von Ordnung und Gesetz und dabei wohl denken mag, so was lesen die Herren gern und halten ihn für einen pflichttreuen Mann. Ja, liebe Frau Menz, so red't er in einem fort zu Haus, und so schreibt er auch, und dann stellt er sich vor meine gute Frau und sagt: „Sieh, Bärbel, ich bin nur ein kleiner Mann, aber das tut nichts: jeder an seinem Fleck, und das weiß ich, ich sorge dafür, daß die Fundamente bleiben, und ich bin eine Stütze von Land und Thron." (277)

Fontane's irony is evident here, particular in the detail about the capital $\mathrm{H}$ for "Herr" of which the obsequious forester is unduly proud. In this quotation, and with regard to the discourse on Ordnung in the novel in general, the critical tone is easy to spot. But in fact, the novel presents a range of characters with different ideological positions, the other most significant being L'Hermite. He is at once a communard and thus the ideological antithesis of Opitz, and though a "Fanatiker", he is clearly also a character who inspires the reader's empathy:

Ein Mitglied der Commune, ja mehr, ein Führer derselben und hat den Erzbischof von Paris erschießen lassen und sollte dann später selbst erschossen werden. [...] er ist grundgescheit und kann alles und weiß alles. Er hat nur eine Menschheitsbeglückungsidee, der er alles opfert und am liebsten einen Erzbischof, einen Empereur, einen Papst. In seinen Ideen ist er ein Fanatiker und tut das Äußerste, sonst ist er wie ein Kind. (343) 
A further ideological aspect, this time a cultural one with significant repercussions for the novel's action, is the nineteenth-century idea of Heimat. As Lehnert is on his way to confront Opitz, he passes a troupe of young girls on an outing to the Schwarzkoppe, singing the Schlesienlied (280):

Schlesierland! Schlesierland!

Du bist es, wo meine Wiege stand!

Ach, werd' ich dich wiedersehn,

Im Schatten deiner Tannen gehn,

Am Hügel meiner Eltern knien

Und sehen, wie die Wolken ziehn?

Auch in der Ferne knüpft mich ein Band

An dich, geliebtes Heimatland.

Lehnert is deeply affected by this, and feels a sense of Heimweh (281) at the thought that he might have to leave home if Opitz brings charges against him, as he has already thought. Significantly, in Lehnert's reasoning, he kills Opitz to stay, rather than have to flee and leave his home.

The narrative function of these various articulated ideologies is firstly to relativize their validity; throughout the novel what counts is less an individual view of the world, and its rightness, but more one's own relationship with others in one's immediate surroundings and ability to act humanely. Here, as so often in Fontane, secondary characters and small details play an important role. In Nogat-Ehre, the Prussian Kaulbars is well known for an exaggerated work ethic and sense of propriety. Indeed, he is irritated at the disorder Lehnert's accident causes because work will have to be put aside in order to go and look for him (442). But what counts is the fact that Kaulbars overcomes his own feelings of resentment and goes himself with his best men to look for Lehnert. What the novel does in passages like this one is reflect on the ways and extent to which our imagination, our ideals and our ideological frameworks influence our moral judgement and action. Discussing Lehnert's case, the Assessor reflects on the contingency, on the situatedness of formal judicial decisions in the face of human character:

„Ich bin kein Anhänger der Abschreckungstheorie. [...] Gerechtigkeit! Was heißt Gerechtigkeit? Was war hier Gerechtigkeit? Dieser Opitz, der für seiner Sünden Schuld hat zahlen müssen...“

„Er war ein Mann in Dienst.“

„[...] Ich habe mir im Gerichtskretscham gestern abend den Fall erzählen lassen und habe dann auch nach Lehnert gefragt, und ob er was tauge oder nicht. Und da habe ich nicht viel Schlimmes gehört. Im Gegenteil. Ein bißchen wirr wie alle Halbgebildeten, die viel Zeitungen und Freiheitsbücher lesen. Aber trotzdem nicht übel. Meinen Segen hat er.“ (320)

Principles, rules, ideals must, in reality, be tempered with a sense of humanity, in this novel about criminality, that means, in fact, accepting human error. It is in this sense that the novel closes, as Geraldine, Espe's wife with a past, interrupts her husband's highminded judgement of Lehnert's end. Or, on a more comic note, as L'Hermite remarks about English, there are so many exceptions that it is not worth learning the rules.

The novel makes a distinction, thus, between ideals and realities, between abstract systems or idealised notions, and the realities we see in front of us in the lives we lead. In this way, the novel associates its criticism of ideals and utopias on the one hand and the spatial structures we have examined above on the other: both Lehnert and Opitz think too much about what is going on "drüben" so that they forget to think about their own actions, they do so literally, brooding about each other, but also they either romanticise 
about home or America (Lehnert) or get carried away with ideas of duty to the crown (Opitz). Indeed, both characters are more similar than is usually assumed in scholarshipboth, not just Opitz, become angry about the way they greet each other, for example. Their thoughts and their actions take them beyond reasonable boundaries, take them on Umwege, and prevent them from concentrating on what is hier.

How do we account then, for the overall positive image of America, if being "drüben" is condemned? Fontane's novel does not condemn utopianism; indeed, comparisons-with ideals, with places, with the past-are an essential mode of true perception as it is presented in the novel, which is full of pairs and contrasts. When Lehnert arrives in Nogat-Ehre and goes to his room he picks up a Bible, and reads a passage that reminds him of his own fate: "Zähle meine Flucht, fasse meine Tränen, ohne Zweifel, du zählest sie. Was können mir die Menschen tun? Ich hoffe auf dich, du hast meine Seele vom Tode gerettet." (345) Moved, he steps to the window sees a mountainous, pine-forested landscape, which recalls Silesia, in much the same way as he seems to meet "Heimat und Glück" when he arrives (332). The narrator underlines that comparison and remembrance are the modes of Lehnert's engagement with his surroundings: “[...] dann sah er wieder hinaus und suchte hinauf, ob er noch andere Punkte zur Vergleichung und Erinnerung fände." (345) Importantly, the moral terms that Siebenhaar discusses with Lehnert, "Zucht" and "Sitte", prefigure those articulated by Obadja. What is at stake, thus, is not the rejection of all ideals, for the novel does not promote an empty relativism. But it does promote the acceptance and tolerance of other views. Christine Brieger has argued that Nogat-Ehre cannot be considered a utopian society because the relationships between individuals are rather unfulfilled. Lehnert's experience there is one of relationships that are "friedlich" rather than "herzlich", in part because of Obadja's rather austere regime. But the overall thrust of the novel seems to imply that true friendships and deep personal relationships are rare. Opitz and Lehnert could never have become true friends; but they could have lived in peace. Once again, L'Hermite supplies a phrase that exemplifies the general theme: "mon cher ennemi".

\section{Conclusion}

For Karl Mannheim, becoming aware of ideology and utopian mentalities as they function in society is "in the last analysis, a quest for reality" (1968: 87). Quitt is such a quest. As we have seen, the fundamental division of the novel into two narrative segments with two opposed settings mirrors a range of other spatial metaphors in the text which create symbolic associations between discourses on moral judgement, on our life with others, and on our perception of reality. If the text as a whole appears to contrast Nogat-Ehre and Silesia, the New World and the old, then these other patterns point instead to a more fundamental point: moral action in this novel is predicated upon realism, perceiving one's real place in the world, rejecting ideas or emotions that lead us astray, being realistic enough to accept the limitations of our principles and the faults of others. In this sense, the novel, despite all its failings, clearly is part of the late Fontane's literary testament: its fundamental question points back to Botho's search for happiness in the lost market garden in Irrungen Wirrungen, forward to Effi's return to Hohen-Cremmen. Its close, in which Geraldine, a woman with a past, utters the final verdict, announces Melusine's conclusion of Fontane's literary testament, Der Stechlin. For the literary historian, Quitt offers a profound insight into Fontane's Weltanschauung. In no other novel, 
with the exception perhaps of Der Stechlin, is the tension so unresolved between balancing fundamentally unprovable truths and visions of the world, with an ethical imperative.

\section{BIBLIOGRAPHY}

BADE James (2015), “Eine gemalte Landschaft? Landscapes in Theodor Fontane's Novel Quitt (1890)”, R. Robertson \& M. White (eds), Theodor Fontane and Cultural Mediation: Translation and Reception in Nineteenth-Century German Literature, Oxford: Legenda, 23-48.

BECKER Sabina (2003), Bürgerlicher Realismus. Literatur und Kultur im bürgerlichen Zeitalter 1840-1900, Tübingen: Francke.

BERBIG Roland et al. (eds) (2010), Fontane Chronik, Berlin: De Gruyter.

BIESTERFELD Wolfgang (1974), Die literarische Utopie, Stuttgart: Metzler.

ClAEYS Gregory \& TOWER SARGENT Lyman (eds) (1999), The Utopian Reader, New York and London: New York Univerity Press.

FONTANE Theodor (1962-1997), Werke, Schriften und Briefe [originally Sämtliche Werke], ed. by Walter Keitel and Helmuth Nürnberger, Munich: Hanser [= 'Hanser Ausgabe' (HA)].

FoNTANE Theodor (1999), Quitt, ed. by Christine Brieger, Berlin: Aufbau.

GRAWE Christian (2000), “Quitt. Roman”, H. Nürnberger \& C. Grawe (eds), Fontane-Handbuch, Stuttgart: Kröner, 584-94.

Howe Patricia (ed.) (2013), Theodor Fontane: Dichter des Übergangs. Beiträge zur Frühjahrstagung der Theodor Fontane Gesellschaft 2010, Würzburg: Königshausen \& Neumann.

JolLES Charlotte (1993), Theodor Fontane, Stuttgart: Metzler.

KAHRMANn Cordula (1973), Idyll im Roman: Theodor Fontane, Munich: Fink.

KUMAR Krishan (1991), Utopianism, Open University Press.

KIRCHENHEIM Arthur (1892), Schlaraffia politica: Geschichte der Dichtungen vom besten Staate, Leipzig: Grunow.

MANNHEIM Karl (1968), Ideology and Utopia, trans. by Louis Wirth and Edward Shils, London: Routledge.

MANUel Frank E. \& MANUEL Fritzie P. (1979), Utopian thought in the Western world, Oxford: Blackwell.

PlETt Bettina (2000), “Der Platz, and dem man gestellt ist. Ein Topos Fontanes und seine bewußseins-geschichtliche Topographie”, H. Delf von Wolzogenand \& H. Nürnberger (eds), Theodor Fontane am Ende des Jahrhunderts. Internationales Symposium des Theodor-Fontane-Archivs zum 100. Todestag Theodor Fontanes (13.-17. September 1998 in Potsdam), 3 vols, Würzburg: Königshausen \& Neumann, 2, 97-107.

PlumPE Gerhard (2005), Theorie des bürgerlichen Realismus. Eine Textsammlung, Stuttgart: Reclam. 
REUTER Hans-Heinrich (1971), "Kriminalgeschichte, Humanistische Utopie und Lehrstück.

Theodor Fontanes Quitt", Sinn und Form, 23, 1371-6.

SCHERPE Klaus R. (2000), “Ort oder Raum? Theodor Fontanes literarische Topographie”, Theodor

Fontane am Ende des Jahrhunderts, 3, 161-9.

UEDING Cornelie (1978), "Utopie auf Umwegen. Zwei Szenen in Fontanes Roman Cécile”, G. Ueding

(ed.), Literatur ist Utopie, Frankfurt am Main: Suhrkamp.

WALKER John (2011), The Truth of Realism: A Reassessment of the German Novel, 1830-1900, Oxford:

Legenda.

\section{NOTES}

1. Fontane's description of the modern novel as "ein unverzerrtes Wiederspiel des Lebens [...], das wir führen" occurs in a review of Paul Lindau (Fontane, 1969, III, 1: 569). All references to Fontane's works, unless otherwise indicated, are to this edition, subsequently cited "HA" (Hanser Ausgabe). Roman numerals refer to sections, italics to volumes within sections.

2. For a discussion of the "return home" as a typical motif of nineteenth-century prose fiction, see Becker (2003: 165-6).

3. See entry 23.11.1889 in Berbig (2010).

4. The Hanser edition of Fontane's letters lists however only two references to Richter, see HA IV, 3: 281 and 528 .

5. Data from the digitalized version of the Grenzboten made available by Bremen University Library: <http://brema.suub.uni-bremen.de/grenzboten> (20 August 2016).

6. Ibid.

7. For Mannheim, ideology is the Weltanschauung of a milieu, age and society; a "utopian state of mind" is one which "is incongruous with the state of reality within which it occurs" (173). Mannheim essentially sees a utopian mentality as being directed to the changing of society. This definition can include a "conservative idea" as a form of utopian mentality, and so does not necessarily imply social progress (206). For our purposes, the notion that a utopia can be a place (in a novel) and part of our thinking suffices (87).

8. HA I, 1: 262. Subsequent references to the novel will be given parenthetically in the text and refer to this edition.

9. Grawe's interpretation is, on the whole, relatively positive.

10. The publication of Biesterfeld's bibliographical survey in the Sammlung Metzler is indicative (Biesterfeld, 1974).

\section{ABSTRACTS}

The principal argument of this essay is that Theodor Fontane's Quitt (1890) can be read as a critical engagement with utopianism. Quitt has previously been analysed as a utopian novel in a narrow sense, specifically because of the Mennonite community in America in which the second half of the novel is set. This analysis is unsatisfactory, however, because it ignores other, associated facets of utopian ways of thinking which permeate the novel, from imagining a 
happier elsewhere, to political ideologies, to ideals of human conduct. This essay proposes an interpretation of the novel in which ideals of various kinds function within the perception of reality, but can also be morally dangerous when they lead human beings away from a positive engagement with the reality in which they find themselves.

Cet article propose une lecture du roman Quitt (1890) de Theodor Fontane mettant en lumière un engagement critique envers l'utopisme. Les interprétations précédentes de Quitt comme roman utopique ont avant tout insisté sur la représentation de la communauté mennonite aux ÉtatsUnis, où se déroule la deuxième partie du roman. Cette approche ignore pourtant d'autres " utopies », des ailleurs divers, des façons de penser utopiques, représentés tout au long de la narration, et qui donnent au roman une cohérence que la recherche a largement négligée. Cet article examine ainsi ces utopies multiples et leur fonction dans la perception de la réalité ; celles-ci peuvent cependant aussi se révéler dangereuses lorsqu'elles empêchent l'homme de s'engager dans son environnement immédiat de façon positive.

\section{INDEX}

Mots-clés: Quitt, Fontane, utopie, réalisme, perception

Keywords: Quitt, Fontane, utopia, Realism, perception

\section{AUTHOR}

\section{MICHAEL WHITE}

University of St. Andrews 